\title{
Analisis Pengaruh Citra dan Kualitas Layanan Terhadap Kepuasan Pasien Serta Implikasinya Pada Komunikasi Pemasaran di Rumah Bersalin Fatimah Kota Bandung
}

\author{
Nugi Mohammad Nugraha ${ }^{1}$, Asep Anwar ${ }^{2}$, M. Sidik Priadana ${ }^{3}$, Oktri Mohammad Firdaus ${ }^{2}$ \\ ${ }^{1}$ Program Studi Manajemen, Universitas Widyatama, Bandung \\ ${ }^{2}$ Program Studi Teknik Industri, Universitas Widyatama, Bandung \\ ${ }^{3}$ Program Pascasarjana, STIE Pasundan, Bandung \\ Email: nugi.mohammad@widyatama.ac.id
}

\begin{abstract}
Abstrak
Penelitian ini dilakukan di latarbelakangi bahwa komunikasi pemasaran di Rumah Bersalin Fatimah Kota Bandung belum optimal. Belum optimalnya komunikasi pemasaran di Rumah Bersalin Fatimah Kota Bandung tersebut, diduga karena kepuasan pasien yang masih rendah, dan rendahnya kepuasan pasien diduga disebabkan oleh Citra dan Kualitas Layanan yang masih rendah. Metode penelitian yang digunakan adalah metode survei dan analisis kuantitatif. Teknik sampling yang digunakan adalah simple random sampling. Analisa Data dengan teknik analisis deskriptif dan analisis jalur (path analysis). Hasil penelitian menunjukkan bahwa citra berada pada kategori cukup baik, kualitas layanan berada pada kategori cukup baik, kepuasan pasien berada pada kategori cukup baik, dan komunikasi pemasaran berada pada kategori cukup baik. Pengaruh secara simultan citra, kualitas layanan terhadap kepuasan pasienRumah Bersalin Fatimah Kota Bandung, adalah sebesar 59,9 sisanya sebesar 40,1\% ditentukan oleh variabel lain. Pengaruh kepuasan pasien terhadap komunikasi pemasaran di Rumah Bersalin Fatimah Kota Bandung adalah sebesar 71,2 \% dan sisanya sebesar 28,8 \% ditentukan oleh variabel lain.
\end{abstract}

Kata Kunci : Citra, Kualitas Layanan, Kepuasan Pasien, dan Komunikasi Pemasaran.

\section{Pendahuluan}

Rumah Bersalin Fatimah merupakan salah satu rumah sakit bersalin yang ada di Ujung Berung, Bandung Timur yang sangatlah perlu memfokuskan pada kualitas pelayanan untuk meningkatkan posisi kompetitifnya agar pasien mencapai kepuasan dan akan merekomendasikan rumah sakit tersebut kepada rekan, keluarga maupun relasi lainnya. Kualitas pelayanan merupakan indikator kinerja bagi penyelenggara pelayanan kesehatan seperti rumah sakit. Rumah sakit akan semakin maju jika kinerjanya dapat dipertahankan. Oleh karena itu pelayanan rumah sakit harus berubah mengarah pada kekuatan pasar sehingga orientasi rumah sakit bergeser dari organisasi sosial kearah sosioekonomi, dengan demikian mempertahankan pelanggan adalah tujuan utama yang harus dicapai. Persepsi pasien tentang kualitas pelayanan merupakan penilaian menyeluruh atas keunggulan suatu jasa atau pelayanan [1]. Menurut Gummesson dalam referensi [1] persepsi terhadap kualitas total akan mempengaruhi citra perusahaan dalam benak pelanggan. Kepuasan pasien merupakan salah satu upaya untuk menciptakan hubungan yang baik antara rumah sakit dengan pelanggan.

Referensi [2] melakukan penelitian untuk menguji pengaruh kualitas layanan terhadap kepuasan pelanggan dalam meningkatkan minat mereferensikan (word of mouth). Hasil pengujian dengan SEM menunjukkan bahwa kualitas pelayanan berpengaruh positif dan signifikan terhadap kepuasan pasien. Hasil temuan dari penelitian [3] menunjukkan bahwa semua variabel kualitas pelayanan secara signifikan memiliki pengaruh terhadap kepuasan konsumen di Rumah Sakit Islam Manisrenggo Klaten.Referensi [4] dalam penelitiannya melakukan penerapan SERVQUAL dan dimensi yang 
digunakan pada penelitian mengacu pada studi yang dilakukan oleh Parasuraman dkk.mengenai kualitas pelayanan.Komunikasi pemasaran berkontribusi pada ekuitas merek dengan menanamkan merek dalam ingatan dan menciptakan citra merek serta mendorong penjualan dan bahkan mempengaruhi nilai pemegang saham.

\section{Kajian Pustaka}

\section{Pengertian Jasa}

Menurut Gronroos dalam referensi [1] mendefinisikan jasa sebagai proses yang terdiri atas serangkaian aktivitas intangible yang biasanya (namun tidak harus selalu) terjadi pada interaksi antara pelanggan dan karyawan jas dan atau sumber daya fisik atau barang dan atau sistem penyedia jasa, yang disediakan sebagai solusi atas masalah pelanggan.Sedangkan menurut referensi [6] jasa merupakan semua aktifitas ekonomi yang hasilnya tidak merupakan produk dalam bentuk fisik/konstruksi yang biasanya dikonsumsi pada waktu yang sama pada waktu dihasilkan dan memberikan nilai tambah (seperti kenyamanan, hiburan, kesenangan, atau kesehatan) atau pemecahan akan masalah yang dihadapi konsumen.

\section{Pengertian Citra}

Referensi [7] menjelaskan bahwa ada dua pendekatan yang dapat digunakan dalam mengukur citra. Pertama adalah merefleksikan cira dibenak konsumen menurut mereka sendiri. Pendekatan ini disebut pendekatan tidak terstruktur (unstructure approach) karena memang konsumen bebas menjelaskan citra suatu objek di pikiran dan benak mereka. Cara yang kedua adalah peneliti menyajikan dimensi yang jelas, kemudian responden berespons terhadap dimensi-dimensi yang dinyatakan itu. Ini disebut pendekatan terstruktur (stuctured approach). Citra didefinisikan sebagai kesan yang diperoleh sesuai pengetahuan dan pengalaman seseorang tentang sesuatu. Citra dibentuk berdasarkan impresi, berdasar pengalaman yang dialami seseorang terhadap sesuatu untuk mengambil keputusan [8]. Sedangkan menurut Lawrence yang dikutip dalam referensi [9]. Citra adalah pancaran atau reproduksi jati diri atau bentuk orang perorangan, benda atau organisasi.

\section{Terbentuknya Sebuah Citra}

Referensi [10] mengemukakan dua teori pembentukan citra :

a. Memberlakukan bahwa citra adalah sebagian besar object determined, yaitu bahwa orang-orang dengan mudah merasakan realitas objek itu.

b. Teori yang lain memberlakukan bahwa citra adalah sebagian besar person determined.

\section{Konsep Kualitas Layanan}

Kualitas pelayanan merupakan komponen penting dalam persepsi konsumen, juga sangat penting dalam pengaruhnya terhadap kepuasan konsumen. Semakin baik kualitas maka jasa yang diberikan maka akan semakin baik pula citra jasa tersebut dimata konsumen. Menurut referensi [11] mengindentifikasikan lima dimensi yang digunakan konsumen dalam mengevalusi kualitas layanan, antara lain adalah Bukti fisik (tangibles), Kehandalan (Reliability), Kepastian (Assurance), Daya tanggap (Responsiveness), dan Empati (Emphaty). Menurut referensi [12] ada 7 dimensi kualitas dalam pelayanan kesehatan, yaitu : jaminan, empati, kehandalan, daya tanggap, tampilan fisik, pelayanan medis dan profesionalisme.Parasuraman dkk..dalam referensi [5] menyatakan sepuluh dimensi dari service quality yang dihasilkan dari penelitiannya, yaitu : Keandalan (Reliability), Ketanggapan (Responsiveness), Kemampuan (Competence), Mudah diperoleh (Accsess), Kehormatan (Courtesy), Komunikasi (Communication), Dapat dipercaya (Credibility), Keamanan (Security), Memahami (Understanding/knowing), Bukti nyata yang kasat mata (Tangibles), Kepuasan konsumen adalah suatu persepsi konsumen terhadap satu jenis pengalaman pelayanan yang dialaminya. Pada dasarnya ada hubungan yang erat antara penentuan kualitas pelayanan dan kepuasan pelanggan [1]. 


\section{Hubungan Citra dengan Kualitas Layanan}

Menurut referensi [13] pengalaman dalam menggunakan jasa merupakan sebuah fungsi dari dua dimensi kualitas yaitu technical quality adalah apa yang diperoleh pelanggan sebagai hasil dari transaksi antara penyedia dan pengguna jasa dan functional quality adalah bagaimana pelanggan memperoleh jasa tersebut. Dua model dimensi kualitas jasa tersebut menentukan citra perusahaan, hal ini karena adanya pengaruh persepsi pelanggan akan kualitas jasa tersebut.

\section{Pengaruh Citra dengan Kepuasan Pasien}

Menurut referensi [13] menyatakan bahwa citra berkolerasi dengan kepuasan pelanggan. Atas dasar pengalaman yang telah dimiliki konsumen (pasien), mereka akan memberikan penilaian dan evaluasi seluruh kinerja layanan rumah sakit Referensi [14] yang meneliti antecedent loyalty pada pengguna jasa GSM di Turki, menemukan bahwa citra berpengaruh positif terhadap loyalitas, di mana word of mouth merupakan salah satu dimensi dari loyalitas.

\section{Pengaruh Kualitas Layanan dengan Kepuasan Pasien}

Semakin baik kualitas pelayanannya, akan semakin tinggi pula kepuasan pelanggan terhadap perusahaan tersebut. Tingginya kualitas pelayanan juga tidak lepas dari dukungan internal perusahaan, terutama dukungan dari sumber daya manusianya [15]. Hubungan antara kualitas pelayanan dan kepuasan secara luasdidokumentasikan dalam literatur pemasaran, hubungan tersebut secara teoritis maupun empiris adalah positif seperti yang telah diteliti oleh referensi [16]. Referensi [17] menyatakan bahwa kualitas jasa merupakan salah satu variabel yang dapat mempengaruhi komunikasi pemasaran atauWord Of Mouth.

\section{Pengaruh Kepuasan Pasien terhadap Komunikasi Pemasaran}

Referensi [18] menyatakan bahwa ketika seorang pemasar mampu menawarkan tingkat kepuasan yang maksimal kepada konsumen, maka konsumen akan memiliki kecenderungan untuk melakukan positive word of mouth. Menurut referensi [2] dalam usaha komunikasi pmasaran, memuaskan pelanggan adalah hal yang sangat wajib. Dalam studi tersebut disebutkan bahwa secara rata-rata, satu pelanggan tidak puas akan mengakibatkan sembilan calon pelanggan lain yang akan menyebabkan ketidakpuasan. Sedangkan pelanggan yang puas hanya akan mengabarkan kepada lima calon pelanggan lain.

\section{Metodologi}

Penelitian ini menggunakan metode deskriptif analisis. Metode deskriptif adalah suatu metode dalam meneliti status kelompok manusia suatu obyek, suatu set kondisi, suatu sistem pemikiran ataupun suatu kelas peristiwa pada masa sekarang. Tujuan penelitian deskriptif ini adalah untuk membuat deskripsi, gambaran atau lukisan secara sistematis, faktual dan akurat mengenai fakta-fakta serta hubungan antar fenomena yang diselidiki. Metoda deskriptif analisis digunakan untuk menguji hipotesis atau menjawab pertanyaan penelitian.

Variabel dalam penelitian ini ditetapkan variabel sebagai berikut:

a. Citra berfungsi sebagai variabel bebas (Independent variable) yang kemudian diberi notasi X1

b. Kualitas Layanan berfungsi sebagai variabel bebas (Independent variable) yang kemudian diberi notasi X2

c. Kepuasan Pasien berfungsi sebagai variabel perantara (Intervening variable) yang kemudian diberi notasi Y.

d. Komunikasi Pemasaran berfungsi sebagai variabel terikat (Dependen variabel) yang kemudian diberi notasi $\mathrm{Z}$.

Dari anggota populasi yang ada peneliti menetapkan jumlah responden sebanyak 63 orang responden.

\section{Pembahasan}

\section{Pengaruh Variabel bebas ( $\mathrm{X}$ ) terhadap variabel terikat ( $\mathrm{Y}$ )}

Analisis jalur digunakan untuk menunjukkan hubungan yang memperlihatkan seberapa besar pengaruh sebuah variabel tertentu baik pengaruh langsung maupun tidak langsung terhadap variabel lainnya. Jadi dalam hal ini persoalannya adalah sebab akibat.Perhitungan koefisien korelasi menggunakan analisis korelasi Pearson Product Moment, dilakukan guna mengetahui seberapa kuat hubungan antara 
beberapa variabel independen yang diteliti. Perhitungan koefisien korelasi menggunakan program SPSS. Hubungan antara variabel Citra (X1) dengan Kualitas Layanan (X2) didapat nilai sebesar 0,673 Sehingga apabila dikonsultasikan dengan tabel interpretasi nilai $\mathrm{r}$ (korelasi), mempunyai tingkat hubungan yang Kuat dan searah karena nilainya positif. Pernyataan di atas dapat diartikan apabila Citra (X1) naik sebesar satu satuan, maka diikuti dengan kenaikan besaran Kualitas Layanan (X2) sebesar 0,673 satuan.

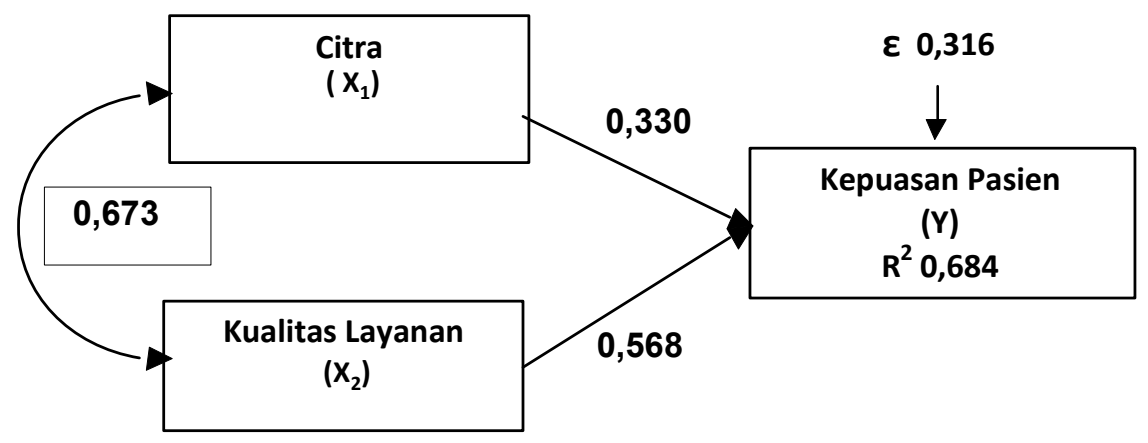

Gambar 1 Pengaruh variabel Citra dan Kualitas Layanan terhadap Kepuasan Pasien

Berdasarkan hasil perhitungan dengan menggunakan program SPSS versi 19 diperoleh besaran koefisien jalur seperti yang dijelaskan pada tabel di bawah ini :

Tabel1 Nilai Koefisien Jalur

Coefficients $^{\mathrm{a}}$

\begin{tabular}{|c|c|c|c|c|c|c|}
\hline & \multirow[t]{2}{*}{ Model } & \multicolumn{2}{|c|}{$\begin{array}{l}\text { Unstandardized } \\
\text { Coefficients }\end{array}$} & \multirow{2}{*}{$\begin{array}{c}\begin{array}{c}\text { Standardized } \\
\text { Coefficients }\end{array} \\
\text { Beta } \\
\end{array}$} & \multirow[t]{2}{*}{$\mathbf{T}$} & \multirow[t]{2}{*}{ Sig, } \\
\hline & & B & Std, Error & & & \\
\hline \multirow[t]{3}{*}{1} & (Constant) & $-33,148$ & 6,723 & & $-4,930$ & 000 \\
\hline & Citra & ,728 & ,217 & ,330 & 3,358 & ,001 \\
\hline & $\begin{array}{l}\text { Kualitas } \\
\text { Layanan }\end{array}$ & ,629 & , 109 & ,568 & 5,788 & ,000 \\
\hline
\end{tabular}

a, Dependent Variable: Kepuasan Pasien

Tabel di atas menggambarkan hasil perhitungan jalur, bahwa variabel X1 mempunyai koefisien jalur sebesar 0,330 dan Variabel X2 mempunyai koefisien jalur sebesar 0,568. Besarnya pengaruh dari masing-masing variabel bebas terhadap variabel terikat baik pengaruh langsung (Direct Effect) maupun pengaruh tidak langsung (Indirect Effect) dapat di lihat pada tabel berikut ini :

Tabel2 Pengaruh langsung dan pengaruh tidak langsungVariabel bebas terhadap variabel terikat

\begin{tabular}{|l|c|r|r|r|r|}
\hline \multirow{2}{*}{ Variabel } & Pengaruh & \multicolumn{2}{|c|}{ Pengaruh Tidak Langsung } & \multirow{2}{*}{$\begin{array}{c}\text { Total } \\
\text { Pengaruh }\end{array}$} \\
\cline { 3 - 5 } & $10,87 \%$ & - & $12,60 \%$ & $12,60 \%$ & $23,47 \%$ \\
\hline Citra & $32,28 \%$ & $12,60 \%$ & - & $12,60 \%$ & $44,89 \%$ \\
\hline Kualitas & & \multicolumn{6}{|c|}{ Total Pengaruh X Ke Y } & $\mathbf{6 8 , 3 5 \%}$ \\
\hline
\end{tabular}

Terlihat bahwa variabel Citra (X1) mempunyai pengaruh langsung sebesar 10,87\% dan pengaruh tidak langsung melalui hubungannya dengan Kualitas Layanan (X2) sebesar 12,60\%, Sehingga total pengaruhnya adalah sebesar 23,47\%. Variabel Kualitas Layanan (X2) mempunyai pengaruh langsung sebesar 32,28\% dan pengaruh tidak langsung melalui hubungannya dengan Citra (X1) sebesar 12,60\%, sehingga total pengaruhnya sebesar 44,89\%. Hasil perhitungan Koefisien determinasi (R kuadrat) yang 
dinyatakan dalam persentase mengambarkan besarnya kontribusi semua variabel bebas yaitu Citra (X1) dan Kualitas Layanan (X2) dalam menentukan variasi Kepuasan Pasien (Y) adalah sebesar 68,35\%. Sedangkan faktor lain yang tidak diteliti dan turut mempengaruhi Komunikasi Pemasaran ditunjukan oleh nilai PyC $=0,316$ atau sebesar 31,645\%.

\section{Pengaruh Variabel bebas ( $\mathrm{Y}$ ) terhadap variabel terikat ( $Z$ )}

Hasil analisis jalur variable Kepuasan Pasien terhadap Komunikasi Pemasaran, dapat dijelas pada gambar di bawah ini :

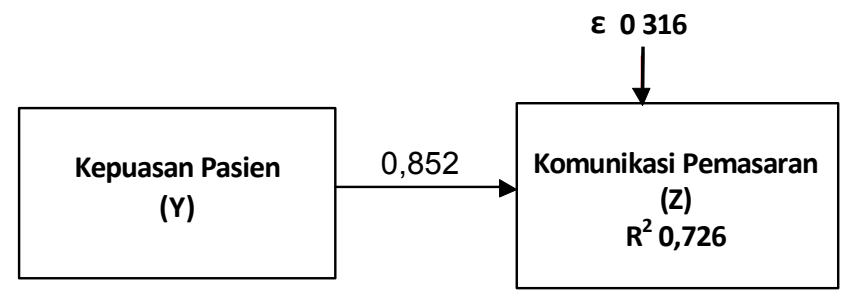

Gambar 2 Pengaruh variabel Kepuasan Pasien terhadap Komunikasi Pemasaran

\section{Uji Validitas}

Uji validasi pada setiap jalur untuk pengaruh langsung adalah sama dengan regresi, menggunakan nilai $\mathrm{p}$ dari uji t yaitu pengujian koefisien regresivariabel dibakukan secara parsial. Untuk koefisien jalur $\mathrm{X} 1=0,330$, diperoleh nilai $\mathrm{t}_{\text {hitung }}$ sebesar 3,358 dengan mengambil taraf signifikansi $\alpha$ sebesar 5\%, maka nilai tabel $=1,98$, sehingga dikarenakan $\mathrm{t}_{\text {hitung }}=3,358$ lebih besar dari $\mathrm{t}_{\text {tabel }}=1,98$, maka $\mathrm{H}_{0}$ ditolak atau dengan kata lain Terdapat Pengaruh yang signifikan antara Citra (X1) terhadap Komunikasi Pemasaran (Y).Untuk koefisien jalur $\mathrm{X}_{2}=0,568$, diperoleh nilai $\mathrm{t}_{\text {hitung }}$ sebesar 5,788 dengan mengambil taraf signifikansi $\alpha$ sebesar $5 \%$, maka nilai $t_{\text {tabel }}=1,98$, sehingga dikarenakan thitung $=5,788$ lebih besar dari $\mathrm{t}_{\text {tabel }}=1,98$, maka $\mathrm{H}_{0}$ ditolak atau dengan kata lain Terdapat Pengaruh yang signifikan antara Kualitas Layanan (X2) terhadap Kepuasan Pasien (Y).Berdasarkan perhitungan diperoleh nilai $\mathrm{F}_{\text {hitung }}$ sebesar 64,801 dimana kriteria penolakan $\mathrm{H}_{0}$ jika $\mathrm{F}_{\text {hitung }}$ lebih besar daripada $\mathrm{F}_{\text {tabel }}$ atau $\mathrm{F}_{0}>\mathrm{F}_{\text {tabel }}$, dengan derajat bebas $\mathrm{v}_{1}=3$ dan $\mathrm{v}_{2}=252-3-1$ dan tingkat kepercayaan 95\%, maka dari tabel distribusi $\mathrm{F}$ didapat nilai $\mathrm{F}_{\text {tabel }}=2,36$. Karena 64,801 lebih besar dari 2,36, maka H0 ditolak, artinya dapat disimpulkan bahwa terdapat hubungan secara linear antara X1 (Citra) dan X2 (Kualitas Layanan), terhadap Y (Kepuasan Pasien), atau dapat diartikan bahwa terdapat pengaruh yang positif dan signifikan secara simultan (bersama-sama) antara $\mathrm{X}_{1}$ (Citra) dan $\mathrm{X}_{2}$ (Kualitas Layanan), terhadap Y (Kepuasan Pasien). Artinya dapat disimpulkan bahwa terdapat hubungan secara linear antara $\mathrm{X}_{1}$ (Citra) dan $\mathrm{X}_{2}$ (Kualitas Layanan), terhadap Y (Kepuasan Pasien), atau dapat diartikan bahwa terdapat pengaruh secara bersamasama antara $\mathrm{X}_{1}$ (Citra) dan $\mathrm{X}_{2}$ (Kualitas Layanan), terhadap Y (Kepuasan Pasien)

Apakah terdapat pengaruh secara simultan/keseluruhan antara Kepuasan Pasien (Y) terhadap Komunikasi Pemasaran (Z). Berdasarkan perhitungan diperoleh nilai $\mathrm{F}$ hitung sebesar 161,886, dimana kriteria penolakan $\mathrm{H}_{0}$ jika $\mathrm{F}_{\text {hitung }}$ lebih besar daripada $\mathrm{F}_{\text {tabel }}$ atau $\mathrm{F}_{0}>\mathrm{F}_{\text {tabel }}$, dengan derajat bebas $\mathrm{v}_{1}=1$ dan $\mathrm{v}_{2}=352-1-1$ dan tingkat kepercayaan 95\%, maka dari tabel distribusi $\mathrm{F}$ didapat nilai $\mathrm{F}_{\text {tabel }}=5,59$. Dikarenakan 161,886 lebih besar dari 5,59, maka $\mathrm{H}_{0}$ ditolak, artinya dapat disimpulkan bahwa terdapat hubungan secara linear antara Kepuasan Pasien (Y) dengan Komunikasi Pemasaran (Z), sehingga dapat diartikan bahwa terdapat pengaruh secara bersama-sama antara Kepuasan Pasien (Y) dengan Komunikasi Pemasaran $(\mathrm{Z})$, sebesar koefisien determinasinya $\left(\mathrm{R}_{2}\right)=0,726$ atau 72,60\% dan pengaruh variabel diluar model sebesar 0,274 atau sebesar 27,40\% (Errorvar $=0,054)$.

\section{Kesimpulan}

Hasil penelitian menunjukkan bahwa citra berada pada kategori cukup baik, kualitas layanan berada pada kategori cukup baik, kepuasan pasien berada pada kategori cukup baik, dan komunikasi pemasaran berada pada kategori cukup baik. Pengaruh secara simultan citra, kualitas layanan terhadap kepuasan pasienRumah Bersalin Fatimah Kota Bandung, adalah sebesar 59,9 sisanya sebesar 40,1\% ditentukan 
oleh variabel lain. Pengaruh kepuasan pasien terhadap komunikasi pemasaran di Rumah Bersalin Fatimah Kota Bandung adalah sebesar 71,2 \% dan sisanya sebesar 28,8 \% ditentukan oleh variabel lain.

\section{Daftar Pustaka}

[1] Tjiptono, F. (2014). Pemasaran Jasa. Jakarta: Gramedia Cawang

[2] Setyawati, I. (2009). Analisis Kualitas Pengaruh Layanan dan Kepuasan Pasien Terhadap Word of Mouth. Tesis Magister Manajemen, Universitas Diponegoro, Semarang.

[3] Wiyono. A dan Wahyuddin, M. (2005). Studi Tentang Kualitas Pelayanan Dan Kepuasan Konsumen Di Rumah Sakit Islam Manisrenggo Klaten. Tesis, Program Pascasarjana Universitas Muhammadiyah Surakarta.

[4] Chaniotakis, E. and Lymperopoulus C. 2009. Service Quality Effect on Satisfaction and Word of Mouth in The Health Care Industry, Managing Service Quality, Vol. 19, No. 2, pp 229 - 242

[5] Tjiptono, F. dan Chandra, G. 2007. Service Quality \& Satisfaction. Yogyakarta : Penerbit ANDI

[6] Lupiyoadi , Rambat. 2001. Manajemen Pemasaran Jasa. Jakarta : PT. Salemba Empat.

[7] Simamora, Henry, 2004, Manajemen Sumber Daya Manusia, Edisi Ketiga, Cetakan Pertama, Bagian Penerbitan STIE YKPN, Yogyakarta.

[8] Alma, Buchari. 2007. Strategi Pemasaran Jasa Pendidikan Tinggi. Bunga Rampai Strategic, Manajemen Bisnis berbasis hasil penelitian. Bandung: Alfabeta

[9] Sutojo, Siswanto. 2004. Membangun Citra Perusahaan.Jakarta: Damar MuliaPustaka.

[10] Kotler, Philip. 2007. Manajemen Pemasaran Jilid 1 . Jakarta: Erlangga.

[11] Kotler, Philip. 2008. Manajemen Pemasaran Jilid 1 . Jakarta: Erlangga.

[12] Hanjon, et al. 2000 Methods of Measuring Health Care Service Quality, Journal of Bussiness Research, Volume 48, New York.

[13] Gronroos, C. 2000. Service Management and Marketing, England : Jhon Wiley and Sons Ltd

[14] Aydin, S., Ozer, G. (2005).The analysis of antecedents of customer loyalty in the Turkish mobile telecommunication Market. Eur. J. Mark., 39(7/8): 910-925.

[15] Chen, Cheng-Nan. 2007, The Relation among Social Capital, Entrepreneurial Orientation, Organizational Resources and Entrepreneurial Performance for New Ventures, Contemporary Management Research, National Cheng Kung University.

[16] Wijayanti, Ari. 2008. Strategi Meningkatkan Loyalitas Melalui Kepuasan Pelanggan (Studi Kasus : Produk Kartu Prabayar Mentari - Indosat Wilayah Semarang). Tesis, Program Magister Manajemen Universitas Diponegoro, Semarang.

[17] Harrison, L. Jean and Walker, 2001. The Measurement Of Word Of Mouth Communication And An Investigation Of Service Quality And Customer Commitment As Potential Antecedents, Journal of Service Research, Vol. 4, No. 1, p. 60-75

[18] Brown, Barry, Dacin and Gunst. 2005. Spreading The Word: Investigating Antecedents of Consumers Positive Word of Mouth Intentions and Behaviors in a retailing Context, Journal the Academy of Marketing Science; Vol. 33. No. 2. pg. 123-138 